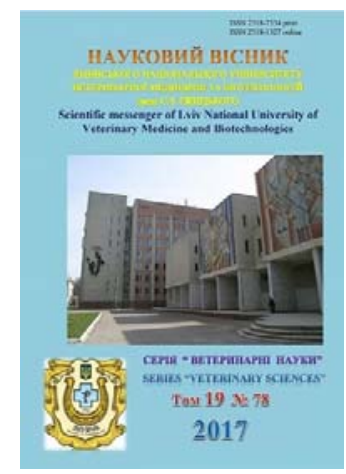

Науковий вісник Львівського національного університету ветеринарної медицини та біотехнологій імені С.З. Гжицького

Scientific Messenger of Lviv National University of Veterinary Medicine and Biotechnologies

doi:10.15421/nvlvet7815

ISSN 2518-7554 print

ISSN 2518-1327 online

$\underline{\text { http://nvlvet.com.ua/ }}$

УДК 636.09:616.98:579.62

\title{
Аналіз результтів лабораторних досліджень щодо бактеріозів у Харківській області
}

\author{
А.В. Ушкалов \\ vetdocman@gmail.com \\ Державний НДІ з лабораторної діагностики та ветеринарно-санітарної експертизи, \\ вул. Донецькка, 30, Київ, 03151, Україна
}

\begin{abstract}
У структурі валової продукиї сільського господарства, продукція тваринництва становить понад 38\%. Загалом завдання галузі тваринництва полягають у виробництві високоякісних продуктів харчування та цинної сировини для харчової та легкої промисловості. Враховуючи зазначене, одним із основних напрямків та завдань Держпродспоживслужби України, зокрема ветеринарної медицини, є здійснення відповідно державного ветеринарно-санітарного контролю, держсавного нагляду (контролю) за дотриманням санітарного законодавства, здоров'ям та благополуччям тварин, безпечністю та окремими показниками якості харчових продуктів, неїстівних продуктів тваринного походження, репродуктивним матеріалом тощьо. Однією з найважливіших ланок підтримання епізоотичного благополуччя, здоров'я тварин $і$ опосередковано людей є своєчасно встановлений діагноз інфекиійних захворювань тварин з метою запобігання економічним збиткам та спалахам захворювань серед споживачів продукиї тваринництва. У статті наведено дані щзодо результатів лабораторних досліджень біоматеріалу від різних видів тварин та дані шодо домінуючих збудників бактеріальних захворювань на території Харківської області. Акиентується увага на суттєвому зниженні кількості біологічного матеріалу, який надходить для діагностичні дослідження, щьо корелює з негативною динамікою кількості продуктивних тварин. Частіше із біоматеріалу виділяли Escherichia coli (збудник колібактеріозу та набрякової хвороби свиней) - 61,7\% випадків, Salmоnеlla spp. (збудник сальмонельозу та пулорозу птичі) - 23,3\% випадків, Streptocoсcиs рпеитопіае (збудник диплококозу/стрептококозу) - 5,1\% випадків, Рseudoтопаs aeruginosa (збудник пседомонозу) - 3,4\% випадків. Крім того, бактеріологічним методом було діагностовано такі захворювання: бешиха свиней, інфекиійний епідидиміт баранів, пастерельоз, лептоспіроз, кампілобактеріоз биків плідників, стафілококоз, американський гнилеиь бджіл, європейський гнилеиь бджіл лістеріоз, брадзот, злоякісний набряк, туберкульоз птииі, аеромоноз риби та сибірка.
\end{abstract}

Ключові слова: лабораторні дослідження, бактеріози, діагностика, тварини.

\section{Анализ результов лабораторных исследований на бактериозы в Харьковской области}

\author{
А.В. Ушкалов \\ vetdocman@gmail.com \\ Государственный НИИ по лабораторной диагностике и ветеринарно-санитарной экспертизы, \\ ул. Донеикая, 30, Киев, 03151, Украина \\ В структуре валовой продукиии сельского хозяйства продукиия животноводства составляет более $38 \%$. Одной из ос- \\ новных задач ветеринарной медицины является осуществление государственного ветеринарно-санитарного контроля и \\ надзора за соблюдением санитарного законодательства, здоровьем и благополучием животных, безопасностью и отдель- \\ ными показателями качества пищевых продуктов, несъедобных продуктов животного происхождения, репродуктивным \\ материалом и т.д. Одним из важнейших звеньев по поддержанию эпизоотического благополучия, здоровья животных и \\ опосредованно-людей является своевременно установленный диагноз инфекиионных заболеваний жсиотных с иелью преду-
}

\section{Citation:}

Ushkalov, A.V. (2017). Analysis of results of laboratory investigations on bacteriosis in Kharkov region. Scientific Messenger LNUVMB, 19(78), 7480 . 
преждения экономических убытков и вспьшек заболеваний среди потребителей продукиии животноводства. В статье приведень данные о результатах лабораторных исследований биоматериала от различньх видов животньх и даннье о возбудителях бактериальных болезней на территории Харьковской области. Акиентируется внимание на существенном снижении количества биологического материала, поступаюшего для диагностических исследований, что коррелирует с отрицательной динамикой количества продуктивных животных. Чаще из биоматериала выделяли Еsсhетісһіа солі (возбудитель колибактериоза и отечной болезни свиней) - 61,7\% случаев, Salmonella spр. (возбудитель сальмонеллеза и пуллороза птицы) - 23,3\% случаев, Streptocoсcиs рпеитопіае (возбудитель диплококоза/стрептококкоза) - 5,1\% случаев, Рsеидотопаs aеruginosa (возбудитель пседомоноза) - 3,4\% случаев. Кроме того, посредством бактериологического метода было диагностировано: рожу свиней, инфекиионный эпидидимит баранов, пастереллез, лептоспироз, кампилобактериоз быков производителей, стафилококкоз, американский гнилец, пчел, европейский гнилец пчел листериоз, брадзот, злокачественный отек, туберкулез птицы, аэромоноз рыбы и сибирская язва.

Ключевые слова: лабораторные исследования, бактериозы, диагностика, животные.

\title{
Analysis of results of laboratory investigations on bacteriosis in Kharkov region
}

\author{
A.V. Ushkalov \\ vetdocman@gmail.com
}

\begin{abstract}
State Research Institute for Laboratory Diagnostics and Veterinary and Sanitary Expertise, street Donetsk, 30, Kyiv, 03151, Ukraine
\end{abstract}

In the structure of gross agricultural output, livestock production is more than 38\%. One of the main tasks of Veterinary Medicine is the implementation of the state veterinary and sanitary control and supervision over the observance of sanitary legislation, animal health and welfare, security and individual indicators of quality of food, non-food products of animal origin, reproductive material, etc. One of the most important links in the maintenance of epizootic well-being, animal health and indirectly people is the timely diagnosis of infectious animal diseases in order to prevent economic losses and disease outbreaks among consumers of livestock products. The article presents data on the results of laboratory studies of biological material from different species, and data on the pathogens of bacterial diseases in the territory of the Kharkiv region. The attention is focused on substantially reducing the amount of biological material coming for diagnostic studies, which correlates with the negative dynamics of the number of productive animals. Most of the isolated biological material Escherichia coli (colibacillosis exciter and swine edema disease) - $61.7 \%$ of cases, Salmonella spp. (The causative agent of salmonellosis and pulloroza birds) - $23.3 \%$ of cases, Streptococcus pneumoniae (pathogen diplokokoza / streptococcosis) - 5.1\% of the cases, Pseudomonas aeruginosa (the causative agent psedomonoza) $-3.4 \%$ of cases. Furthermore, by bacteriological method was diagnosed: swine erysipelas, infectious epididymitis sheep, pasteurellosis, leptospirosis, campylobacteriosis manufacturers bulls stafilokokkoz, american foulbrood bees, bees european foulbrood listeriosis, braxy, malignant edema, tuberculosis poultry, fish and aeromonas, anthrax.

Key words: laboratory tests, bacteriosis, diagnostics, animals.

\section{Вступ}

Тваринництво є важливою галуззю сільського господарства. Від рівня його розвитку залежить наповнення ринку висококалорійними продуктами харчування - м'ясом, молочними продуктами, яйцями тощо. Тваринництво забезпечує сировиною харчову i легку промисловість (м'ясо, молоко, шкіра, вовна, віск, пух тощо), і навіть виробництво цілої низки лікувальних засобів. В умовах затяжної кризи сільського господарства тваринництво України відреагувало скороченням чисельності поголів'я, зниженням продуктивності та зниженням рівня фізіологічної стійкості тварин до дії агресивних мікроорганізмів, в зв'язку з чим відповідно підвищується рівень захворюваності та загибелі сприйнятливих тварин від мікробних агентів (Holovko et al., 2002; Ushkalov, 2002).

Своєчасно та швидко встановлений діагноз $є$ запорукою вдалого та якісного лікування тварин або ж встановлення карантинних заходів при спалахах інфекційних захворювань бактеріальної етіології, що в свою чергу запобігає незапланованим збиткам та забезпечує споживача якісними продуктами харчування.

Метою даної роботи є проведення аналізу результатів бактеріологічних досліджень, проведених в дер- жавних лабораторіях ветеринарної медицини у Харківській області.

\section{Матеріал та методи досліджень}

Аналіз епізоотичної ситуації проводили, використовуючи інформацію Державної служби України 3 питань безпечності харчових продуктів та захисту споживачів, дані ДНДІЛДВСЕ, звітні дані Харківського філіалу ДНДІЛДВСЕ та міжрайонних і районних лабораторій ветеринарної медицини Харківської області. Під час виконання роботи використовували порівняльно-історичний, статистичний методи дослідження і епізоотологічний аналіз.

\section{Результати та їх обговорення}

На Харківщині поголів'я копитних тварин в індивідуальних господарствах громадян станом на 01.12.2015 року становило - 155336 голів, птиці 1763039 голів, кролів - 1125 голів, бджолосімей та пасік - 5467.

У 172 (в т. ч. 14 племінних) господарствах по утриманню ВРX за молочним та м'ясним напрямками утримувалося 96188 голів; у 96 господарствах (в т. ч. 4 племінних) по утриманню свиней - 190141 голів; в 
господарствах утримувалося 7712 голів ДРХ та 1008 голів коней. У 24 птахогосподарствах області (в т. ч. 3 племінних) утримувалося 2750114 голів птиці (кури, індики, перепілки, качки та гуси). Поголів'я кролів та норок становить - 29703 голів, бджолосімей та пасік - 2012 і 27 відповідно.

У Харківській області лабораторні дослідження 3 метою виявлення збудників хвороб бактеріальної етіології тварин проводяться фахівцями бактеріологічного відділу Харківського філіалу Державного науково-дослідного інституту з лабораторної діагностики та ветеринарно-санітарної експертизи, а також бактеріологічних відділів районних, міжрайонних державних лабораторій ветеринарної медицини. На характер та інтенсивність прояву спалахів бактеріальних хвороб в Харківській області впливають різноманітність і контрастність природно-господарських умов різних районів (Stehnii et al., 2011). Загалом за 20102015 роки на території області за допомогою бактеріологічних досліджень підтверджено 1650 випадків захворювання тварин (табл. 1).

Аналіз досліджень на бактеріальні хвороби

Таблиия 1

\begin{tabular}{|c|c|c|c|c|}
\hline \multirow{2}{*}{ Роки } & Кількість зразків біологічного & \multirow{2}{*}{ Проведено досліджень } & \multicolumn{2}{|c|}{ Діагноз встановлено } \\
\cline { 3 - 5 } & матеріалу & 39804 & 405 & абс. \\
\hline 2010 & 39948 & $27916 \downarrow$ & 216 & 0,77 \\
\hline 2011 & $28009 \downarrow$ & $27474 \downarrow$ & 210 & 0,76 \\
\hline 2012 & $27548 \downarrow$ & $27456 \downarrow$ & 146 & 0,88 \\
\hline 2013 & $27524 \downarrow$ & $21347 \downarrow$ & 216 & 1,25 \\
\hline 2014 & $21468 \downarrow$ & $17352 \downarrow$ & 1434 & $0,88 \%$ \\
\hline 2015 & $17718 \downarrow$ & 161349 & & \\
\hline Всього & 162215 & & & \\
\hline
\end{tabular}

Аналіз одержаних даних свідчить про стабільне зниження кількості біоматеріалу від тварин, який надходив для проведення діагностичних досліджень в державні лабораторії, що на нашу думку, пов'язано $з$ суттєвим зменшенням поголів'я тварин в області, які $\epsilon$ резервуаром збудників бактеріальних хвороб.

Так, за даними Держкомстату, в період із 1980 до 2010 рр. в Україні кількість великої рогатої худоби зменшилася із 25552 тис. голів до 4826,7 тис. голів, тобто на $81,1 \%$. Кількість дрібної рогатої худоби зменшилася $з 9$ 184,1 тис. голів до 1832,5 тис. голів (зниження на понад 80\%), а свиней із 20149,4 тис. голів до 7 576,6 тис. голів (зниження на 62,4\%) (Rublenko and Skrypnyk, 2016). Викликає занепокоєн- ня той факт, що лише за рік (з лютого 2016 по лютий 2017) поголів'я свиней скоротилось на $10,5 \%$ - до 6,3 млн. голів і складало приблизно 0,15 свині на одного жителя України, що стало навіть на 0,5\% нижче від історичного мінімуму, зафіксованого у 2005 році.

Аналіз результатів бактеріологічних досліджень за період 2010-2015 pp., свідчить про те, що найбільш часто захворювання тварин зумовлювали Escherichia coli (збудник колібактеріозу та набрякової хвороби свиней) - 61,7\% випадків, Salmonella spp. (збудник сальмонельозу та пуллорозу птиці) - 23,3\% випадків, Streptococcus pneumoniae (збудник диплококозу/стрептококозу) - 5,1\% випадків, Pseudomonas aeruginosa (збудник пседомонозу) - 3,4\% випадків.

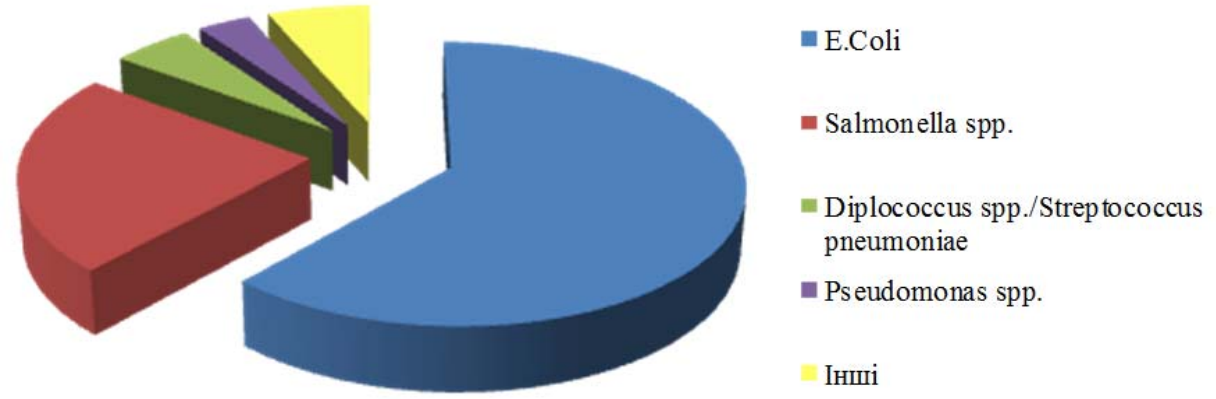

Рис. 1. Збудники хвороб бактеріальної етіології за 2010-2015 рр. (за даними звітності бактеріологічного відділу Харківського філіалу ДНДІЛДВСЕ)

При лабораторних бактеріологічних дослідженнях надісланого патологічного матеріалу (10 789 зразків) на колібактеріоз (ешерихіоз) діагноз встановлено у 986 випадках, в тому числі: 494 - колібактеріоз птиці, 350 - колібактеріоз великої рогатої худоби, 130 колібактеріоз свиней, 9 - колібактеріоз дрібної рогатої худоби і 3 випадки колібактеріозу хутрових звірів. Із 572 зразків надісланих діагностики набрякової хвороби у 23 випадках діагноз було підтверджено.
Щодо серогрупової приналежності виділених культур ешерихій можна констатувати таке: найчастіше були ідентифіковані серотипи О26 та О15 у культур, виділених від птиці (164 та 150 відповідно); серотипи O141 (42) та О9 (23) ідентифіковано серед культур, ізольованих від ВРХ; варто зазначити, що серотип О141 ідентифіковано у птиці у 11 випадках, а серотип О9 виявлено у 3 культур, виділених від свиней. Визначення серотипової приналежності провели лише у 
51,1\% культур (370 культур виділених від птиці, 75 культур - від ВРХ, 55 - від свиней, 4 від інших видів). У інших випадках діагноз встановлювали за результатами біологічної проби на білих мишах.
У табл. 2 представлені дані щодо серотипової приналежності виділених ешерихій.

Серологічні варіанти Escherichia coli, які виділені при проведенні бактеріологічних досліджень від різних видів тварин за період 2010-2015 рр

\begin{tabular}{|c|c|c|c|c|}
\hline \multirow{2}{*}{$\begin{array}{c}\text { Результати визначен- } \\
\text { ня серотипу }\end{array}$} & \multicolumn{4}{|c|}{ Біоматеріал від } \\
\hline & BPX & Свиней & Птиці & Білих мишей \\
\hline $\mathrm{O} 1$ & 2 & 2 & & \\
\hline $\mathrm{O} 2$ & 2 & 5 & 13 & \\
\hline O9 & 23 & 4 & & \\
\hline $\mathrm{O} 11$ & & & 8 & \\
\hline $\mathrm{O} 15$ & & 5 & 150 & \\
\hline $\mathrm{O} 26$ & 3 & 5 & 164 & \\
\hline O101 & 1 & 22 & 3 & \\
\hline Ant25 & & & 3 & \\
\hline O117 & & 3 & & \\
\hline K88AC & & & 12 & \\
\hline O139 & & 6 & & \\
\hline O141 & 42 & & 11 & \\
\hline $\mathrm{O} 78$ & 1 & & & \\
\hline O149 & 2 & & & \\
\hline K88AB & & 1 & 6 & \\
\hline O119 & 1 & & & \\
\hline O115 & & 2 & & 2 \\
\hline Всього & & & & \\
\hline
\end{tabular}

За даними Центральної СЕС, найвищі рівні захворюваності на сальмонельоз з тенденцією до зростання реєструють у Харківській, Запорізькій, Дніпропетровській, Чернігівській областях, АР Крим та в місті Київ. У Харківській області захворювання птиці на сальмонельоз/пуллороз реєструють щорічно (Polishchuk et al., 2012).

Із 56937 зразків, надісланих на дослідження від різних птахівничих господарств на сальмонельоз, діагноз встановлено у 382 випадках, в тому числі від птиці досліджено 53440 зразків (патологічний матеріал, завмерлі ембріони) - діагноз на сальмонельоз встановлено у 297 випадках; із 1647 проб біоматеріалу від ВРХ і 830 проб від ДРХ діагноз на сальмонельоз підтверджено у 8 випадках (4+4); при досліджені
82 зразків біоматеріалу від хутрових звірів діагноз на сальмонельоз встановлено в 1 випадку. Із іншого біологічного матеріалу (938 зразків) збудник сальмонельозу виділено в 1 випадку.

У 2014 році в Дергачівському районі Харківської області у ТОВ ТБ «Богодухівська птахофабрика» при дослідженні матеріалу відповідно до вимог програми щодо контролю сальмонельозу (трупи, змиви, яйце, корми, вода, фекалії) було виділено збудника сальмонельозу - Salmonella pullorum (табл. 3). Згідно з чинною інструкцією з профілактики та ліквідації сальмонельозу птиці від 2 вересня 2010 р. за №774/18069 господарство оголошено неблагополучним, ввели карантинні обмеження (Instruktsii z profilaktyky ta likvidatsii salmonelozu ptytsi, 2010).

Табличя 3

Інформація щодо бактеріологічних досліджень патологічного матеріалу надісланого 3 «Богодухівської п/ф» 25.03.2014 р. - 11.06.2014 p.

\begin{tabular}{|c|c|c|c|c|c|}
\hline $\begin{array}{c}\text { Дата надхо- } \\
\text { дження }\end{array}$ & $\begin{array}{c}\text { Номер екс- } \\
\text { пертизи }\end{array}$ & $\begin{array}{c}\text { Назва мате- } \\
\text { ріалу }\end{array}$ & $\begin{array}{c}\text { Кількість } \\
\text { проб }\end{array}$ & $\begin{array}{c}\text { Результат } \\
\text { бакт. досліджень }\end{array}$ \\
\hline 25.03 .2014 & 00262 & Змиви & 6 & $1,2,3,4$ & Не виділено \\
\hline 26.03 .2014 & 000330 & Комбікорм & 2 & Не виділено \\
\hline 27.03 .2014 & 000320 & Яйце & 9 & $10,12,13,15,17,18,19,20$ & Не виділено \\
\hline 27.03 .2014 & 000319 & Трупи & 54 & $1,2,4,5,6,7,8,9,10,12,13,15$, \\
$16,17,18,19,20,21$ & $\begin{array}{c}\text { S. pullorum (№12, } \\
13,15,20,21)\end{array}$ \\
\hline 9.04 .2014 & 000479 & Фекалії & 90 & $18,20,21$ & Не виділено \\
\hline 9.04 .2014 & 000481 & Комбікорм & 2 & 16,17 & Не виділено \\
\hline 9.04 .2014 & 000482 & Яйце & 12 & $1,2,4-10,17,18$ & Не виділено \\
\hline 9.04 .2014 & 000489 & Трупи & 36 & $7,10,18,17,12,4,5,6,8,9,16$ & Не виділено \\
\hline 16.0 .2014 & 000557 & Трупи & 36 & $7,10,18,17,12,4,5,6,8,9,16$ & Не виділено \\
\hline 16.0 .2014 & 000553 & Яйце & 12 & $1-10,16-18$ & Не виділено \\
\hline 16.0 .2014 & 000558 & Фекалії & 90 & $12,13,15$ & Не виділено \\
\hline 16.0 .2014 & 000556 & Комбікорм & 2 & 16,17 & Не виділено \\
\hline 23.04 .2014 & 000624 & Вода & 1 & $1,2,4$ & Не виділено \\
\hline 23.04 .2014 & 000622 & Фекалії & 90 & 12 & Не виділено \\
\hline 23.04 .2014 & 000621 & Яйце & 12 & $1,2,4,5,6,7,8,9,10,16,17,18$ & Не виділено \\
\hline
\end{tabular}




\begin{tabular}{|c|c|c|c|c|c|}
\hline $\begin{array}{c}\text { Дата надхо- } \\
\text { дження }\end{array}$ & $\begin{array}{c}\text { Номер екс- } \\
\text { пертизи }\end{array}$ & $\begin{array}{l}\text { Назва мате- } \\
\text { ріалу }\end{array}$ & $\begin{array}{l}\text { Кількість } \\
\text { проб }\end{array}$ & № пташників, цехів & $\begin{array}{c}\text { Результат } \\
\text { бакт. досліджень }\end{array}$ \\
\hline 23.04 .2014 & 000619 & Трупи & 36 & $1,2,4,5,6,7,8,9,10,16,18,17$ & $\begin{array}{c}\text { S. pullorum (№7, } \\
17,18)\end{array}$ \\
\hline 23.04 .2014 & 000623 & Комбікорм & 2 & 16,17 & Не виділено \\
\hline 30.04 .2014 & 000678 & Фекалії & 90 & $5,8,9$ & Не виділено \\
\hline 30.04 .2014 & 000679 & Яйце & 12 & $1,2,4,5,6,7,8,9,10,16,17,18$ & Не виділено \\
\hline 30.04 .2014 & 000680 & Трупи & 12 & $1,2,4-10,16-17$ & Не виділено \\
\hline 30.04 .2014 & 000681 & Комбікорм & 2 & 4,6 & Не виділено \\
\hline 08.05 .2014 & 000736 & Фекалії & 90 & $6,10,16$ & Не виділено \\
\hline 08.05 .2014 & 000737 & Трупи & 12 & $1,2,4,5,6,7,8,9,10,16,17,18$ & Не виділено \\
\hline 08.05 .2014 & 000738 & Яйце & 12 & $1,2,4,5,6,7,8,9,10,16,17,18$ & Не виділено \\
\hline 08.05 .2014 & 000735 & Комбікорм & 2 & 6,11 & Не виділено \\
\hline 15.05 .2014 & 000765 & Яйце & 12 & $1,2,4,5,6,7,8,9,10,16,17,18$ & Не виділено \\
\hline 15.05.2014 & 000766 & Фекалії & 90 & $6,10,16$ & Не виділено \\
\hline 15.05 .2014 & 000768 & Трупи & 12 & $1,2,4,5,6,7,8,9,10,16,17,18$ & Не виділено \\
\hline 15.05 .2014 & 000770 & Комбікорм & 2 & 4,6 & Не виділено \\
\hline 21.05 .2014 & 000863 & Яйце & 12 & $1,2,4,5,6,7,8,9,10,16,17,18$ & Не виділено \\
\hline 21.05 .2014 & 000864 & Комбікорм & 2 & 17,18 & Не виділено \\
\hline 28.05 .2014 & 000946 & Трупи & 9 & $1,2,4,5,6,8,9,10,16$ & Не виділено \\
\hline 28.05 .2014 & 000947 & Фекалії & 180 & $5,8,9,10,6,16,4,6$ & Не виділено \\
\hline 28.05 .2014 & 000945 & Комбікорм & 2 & 4,6 & Не виділено \\
\hline 05.06 .2014 & 001049 & Фекалії & 90 & $1,2,4$ & Не виділено \\
\hline 05.06 .2014 & 001059 & Трупи & 9 & $1,2,4,5,6,8,9,10,16$ & S. pullorum (№10) \\
\hline 05.06 .2014 & 001058 & Яйце & 9 & $1,2,4,5,6,16,8,9,10$ & Не виділено \\
\hline 05.06 .2014 & 001055 & Комбікорм & 2 & 4,6 & Не виділено \\
\hline 11.06 .2014 & 001108 & Трупи & 9 & $1,2,4,5,6,8,9,10,16$ & Не виділено \\
\hline 11.06 .2014 & 001109 & Яйце & 9 & $1,2,4,5,6,8,9,10,16$ & Не виділено \\
\hline 11.06 .2014 & 001111 & Фекалії & 90 & $5,8,9$ & Не виділено \\
\hline 11.06 .2014 & 00110 & Комбікорм & 2 & 4,6 & Не виділено \\
\hline
\end{tabular}

Необхідно зазначити, що станом на 01.07.2016 року вказане господарство не було оздоровлене (Zvitni dani Holovnoho upravlinnia Derzhprodspozhyvsluzhby v Kharkivskii oblasti, 2015).

Аналіз результатів бактеріологічних досліджень свідчить, що на території області в період 20102015 рр. циркулювало перважно 9 серологічних варіантів сальмонел. Щорічно із надісланих зразків (п/м, завмерлі ембріони, м'ясо вимушено забитих тварин, тощо) виділяли від 44 (у 2015 році) до 86 (у 2010 році) ізолятів сальмонел. Так, серед виділених і ідентифікованих сальмонел останніми роками домінують $S$. pullorum (166 культури) - 71,8\% від загальної кількості типованих культур, S. typhimurium (22 культури) $9,5 \%$, та $S$. nigeria (12 культур) - 5,1\% (табл. 4). Варто відзначити, що вперше за останні роки 2012 році було виділено ізолят $S$. nigeria, при дослідженнях зразків, надісланих із господарства «Курганський бройлер» Балаклійського району. варіанти Salmonella spp., які виділен при проведенні бактеріологічних досліджень від різних видів тварин за період 2010-2015 pр.

\begin{tabular}{|c|c|c|c|c|c|c|c|}
\hline \multirow{2}{*}{ Серологічні варіанти } & \multicolumn{7}{|c|}{ Біологічний матеріал від } \\
\hline & BPX & Свиней & Птиці & Ембріонів & Вим. забій (свині) & ДРХ & $\begin{array}{l}\text { Інших } \\
\end{array}$ \\
\hline S. enteritidis & & 1 & 1 & & 1 & 2 & \\
\hline S. dublin & 2 & & & & & & \\
\hline S. cholera suis & & 7 & 1 & & & & \\
\hline S. typhy suis & & 3 & & & & & \\
\hline S. typhymurium & 1 & & 18 & & & 2 & 2 \\
\hline S. gallinarum & & & 6 & 3 & & & \\
\hline S. pullorum & & & 112 & 54 & & & \\
\hline S. newport & & 1 & 3 & & & & \\
\hline S. nigeria & & & 12 & & & & \\
\hline ВСЬОГО & & & & 231 кул & & & \\
\hline
\end{tabular}

Із 382 випадків встановлення діагнозу на сальмонельоз 231 культура була ідентифікована як за культурально-морфологічними, біохімічними, так i за серологічними ознаками (3 від ВРХ, 12 від свиней, 153 від птиці, 57 - від завмерлих ембріонів, 2 культури від вимушено забитих тварин, 2 від ДРХ та 2 від інших видів біоматеріалу). В решті випадків (за відсу- тності у деяких лабораторіях діагностичних сироваток діагноз був встановлений на підставі морфологічних, культуральних біохімічних характеристик виділених культур та біопроби на лабораторних тваринах.

При дослідженні 3042 зразка патологічного матеріалу $(51,4 \%$ - від свиней, 25,7\% від ВРХ, 18,4\% - від птиці, 3,9\% - від ДРХ, 0,52\% - від хутрових звірів та 
інші види матеріалу) на стрептококоз діагноз було підтверджено у 84 випадках (табл. 5).

Табличя 5

Результати досліджень на стрептококову інфекцію

\begin{tabular}{|c|c|c|c|}
\hline Біоматеріал від & Абс $/ \%$ & $\begin{array}{c}\text { Кількість } \\
\text { зразків }\end{array}$ & $\begin{array}{c}\text { Виділено } \\
\text { культур }\end{array}$ \\
\hline \multirow{2}{*}{ Свиней } & абс. & 1561 & \multirow{2}{*}{27} \\
\hline & $\%$ & $51,4 \%$ & \\
\hline \multirow{2}{*}{ BPX } & абс. & 784 & \multirow{2}{*}{9} \\
\hline & $\%$ & $25,7 \%$ & \\
\hline \multirow{2}{*}{ Птиці } & абс. & 560 & \multirow{2}{*}{34} \\
\hline & $\%$ & $18,4 \%$ & \\
\hline \multirow{2}{*}{ ДРХ } & абс. & 121 & \multirow{2}{*}{11} \\
\hline & $\%$ & $3,9 \%$ & \\
\hline \multirow{2}{*}{$\begin{array}{c}\text { Хутрових звірів та } \\
\text { ін. }\end{array}$} & абс. & 8 & \multirow{2}{*}{3} \\
\hline & $\%$ & $0,26 \%$ & \\
\hline
\end{tabular}

Цікаво, що найбільшу кількість культур (40,5\%) збудника стрептококозу виділено від птиці - 34, а від свиней і ВРХ 27 (32,2\%) та 9 (10,7\%) культур відповідно. При дослідженні зразків біоматеріалу від ДРХ і хутрових звірів виділено $11(13,1 \%)$ та $3(3,6 \%)$ культур відповідно.

Аналіз результатів бактеріологічних досліджень свідчить, що доволі часто з патологічного матеріалу виділяли Pseudomonas aeruginosa: при дослідженні 19374 зразків завмерлих ембріонів було виділено 31 культуру збудника, при дослідженні 4030 проб патологічного матеріалу від дорослої птиці діагноз на псевдомоноз встановлено в 19 випадків, а з 104 проб патматеріалу від свиней було ізольовано 7 культур Pseudomonas aeruginosa (табл. 6).

Таблиця 6

Результати досліджень на псевдомоноз у 2010-2015 pp.

\begin{tabular}{|c|c|c|}
\hline Біоматеріал & $\begin{array}{c}\text { Кількість } \\
\text { зразків }\end{array}$ & $\begin{array}{c}\text { Виділено } \\
\text { культур }\end{array}$ \\
\hline Завмерлі ембріони & 19374 & 31 \\
\hline Птиця & 4030 & 19 \\
\hline Свині & 104 & 7 \\
\hline
\end{tabular}

За період, що піддається аналізу (табл. 7), бактеріологічним методом встановлено діагноз на бешиху свиней (22 випадки), інфекційний епідидиміт баранів (10 випадків), пастерельоз (15 випадків), лістеріоз (10 випадків), стафілококоз (8 випадків), туберкульоз птиці (8 випадків), аеромоноз риби (8 випадків), злоякісний набряк (5 випадків), кампілобактеріоз у биків плідників (4 випадки), брадзот (4 випадки), американський та європейський гнильці - (3 і 2 випадки відповідно), лептоспіроз (1 випадок), сибірка (1 випадок) у свині в приватному секторі Чугуївського району (Zvitni dani Holovnoho upravlinnia Derzhprodspozhyvsluzhby v Kharkivskii oblasti, 2015).

Частіше із біоматеріалу виділяли Escherichia coli (збудник колібактеріозу та набрякової хвороби свиней) - 61,7\% випадків, Salmonella spp. (збудник сальмонельозу та пуллорозу птиці) - 23,3\% випадків, Streptococcus pneumoniae (збудник диплококозу/стрептококозу) - 5,1\% випадків, Pseudomonas aeruginosa (збудник пседомонозу) - 3,4\% випадків. Крім того, бактеріологічним методом було діагносто- вано такі захворювання: бешиха свиней, Інфекційний епідидиміт баранів, пастерельоз, лептоспіроз, кампілобактеріоз биків плідників, стафілококоз, американський гнилець бджіл, європейський гнилець бджіл лістеріоз, брадзот, злоякісний набряк, туберкульоз птиці, аеромоноз риби та сибірка.

Таблиця 7

Результати бактеріологічних досліджень щодо збудників хвороб, які зустрічаються поодиноко за період 2010-2015 рp.

\begin{tabular}{|l|c|c|}
\hline \multicolumn{1}{|c|}{ Назва захворювання } & $\begin{array}{c}\text { Кількість } \\
\text { зразків }\end{array}$ & $\begin{array}{c}\text { Кількість } \\
\text { позитивних } \\
\text { результатів }\end{array}$ \\
\hline Бешиха свиней & 1138 & 22 \\
\hline Інфекційний епідидиміт баранів & 151 & 10 \\
\hline Пастерельоз & 49884 & 15 \\
\hline Лептоспіроз & 80 & 1 \\
\hline $\begin{array}{l}\text { Кампілобактеріоз биків } \\
\text { плідників }\end{array}$ & 1495 & 4 \\
\hline Стафілококкоз & 665 & 8 \\
\hline Сибірка & 847 & 1 \\
\hline Американський гнилець бджіл & 1527 & 3 \\
\hline Свропейський гнилець бджіл & 1526 & 2 \\
\hline Лістеріоз & 22 & 10 \\
\hline Брадзот & 24 & 4 \\
\hline Злоякісний набряк & 5 & 5 \\
\hline Туберкульоз птиці & 24 & 8 \\
\hline Аеромоноз риби & 74 & 8 \\
\hline
\end{tabular}

\section{Висновки}

Наведено дані стосовно захворювання тварин на бактеріози, підтверджених за допомогою лабораторних досліджень всього на території: області зареєстровано захворювання тварин, зумовлених 17 бактеріальними патогенами різних родів і видів, які спричиняли 18 нозологічних одиниць захворювань у тварин. Встановлені домінуючи серологічні варіанти ешерихій та сальмонел, які зумовлювали захворювання птиці, ВРХ, свиней.

Перспективи подальших досліджень. Одержані дані будуть використані при плануванні досліджень 3 метою діагностики інфекційних хвороб тварин в Харківській області та вдосконалення системи моніторингу бактеріозів.

\section{Бібліографічні посилання}

Holovko, A.M., Ushkalov, V.O., Didok, Yu.V., Rebro, K.I. (2002). Osoblyvosti epizootolohii salmonelozu porosiat $\mathrm{v}$ Kharkivskii oblasti. Zbirnyk materialiv naukovo-praktychnoi konferentsii «Suchasni veterynarni ta tekhnolohichni aspekty svynarstva», 28-29 bereznia 2002 r., K., 24-26 (in Ukrainian).

Ushkalov, V.O. (2002). Osoblyvosti epizootolohii salmonelozu teliat u Kharkivskii oblasti. Visnyk BDAU. Bila Tserkva. 21, 233-236 (in Ukrainian).

Stehnii, B.T., Bezuhlyi, M.D., Bisiuk, I.Yu., Rublenko, M.V. (2011). Aktualni problemy biobezpeky ta biozakhystu shchodo rozrobky ta vyrobnytstva imunobiolohichnykh preparativ dlia veterynarnoi medytsyny. Veterynarna medytsyna : mizhvid. temat. nauk. zb. Kharkiv. 95, 5-10 (in Ukrainian). 
Zvitni dani Holovnoho upravlinnia Derzhprodspozhyvsluzhby $\mathrm{v}$ Kharkivskii oblasti (2015). Kharkiv (in Ukrainian).

Polishchuk, N.M., Kozyrieva, V.H., Koviazina, L.S., Tsviatkova, V.O., Serhach, O.M. (2012). Epidemiolohichni osoblyvosti salmoneloziv na terytorii Zaporizkoi oblasti. Zaporozhskyi medytsynskyi zhurnal, Zaporizhzhia. 5(74), 46 (in Ukrainian).

Stehnii, B.T., Hliebova, K.V., Petrenchuk, E.P., Zaremba, I.A., Maiboroda, O.V. (2013). Analiz epizootychnoho monitorynhu bakterialnykh zakhvoriuvann silskohospodarskoi, dykoi ta dekoratyvnoi ptytsi na terytorii skhodu Ukrainy. Veterynarna medytsyna: mizhvid. temat. nauk. zb. Kharkiv. 97, 232 (in Ukrainian).

Instruktsii z profilaktyky ta likvidatsii salmonelozu ptytsi (2010), 774/18069 (in Ukrainian).

Rublenko, O.I., Skrypnyk, V.H. (2016). Analiz danykh epizootychnykh spalakhiv sybirky na terytorii Ukrainy (perid 1994-2016 rr.). Naukovyi visnyk veterynarnoi medytsyny, 1 (in Ukrainian).

Statystychni danni Holovnoho upravlinnia statystyky U Kharkivskii oblasti (in Ukrainian).

Received 4.09.2017 Received in revised form 30.09.2017 Accepted 5.10.2017 